\title{
Inductive Technology for Creating an Electronic Reference Database for Foundry Production
}

\section{Liešanas ražošanas induktīva tehnologija elektroniskās datubāzes izveidošanai}

\author{
Olena Tokova ${ }^{1}$, Volodymyr Doroshenko ${ }^{2}$, Olena $\mathrm{Mul}^{3}$ \\ ${ }^{1}$ International Research and Training Center for Information Technologies and Systems, Ukraine \\ ${ }^{2}$ Physical-and-Technological Institute of Metals and Alloys, Ukraine \\ ${ }^{3}$ Ternopil National Ivan Puluj Technical University, Ukraine
}

\begin{abstract}
The method for developing an information electronic directory in the field of foundry production, which contains a database of metals and alloys, is proposed. The database is designed to facilitate development of the foundry production technology, including the analysis of available raw materials, target selection of casting components, as well as the choice of cooling modes in order to obtain high quality castings.
\end{abstract}

Keywords - Database of metals and alloys, decision support, casting cooling, information technology.

\section{INTRODUCTION}

At present, the most common method of obtaining metal products of a given quality, complexity and shape is founding, during which the casting of metal or alloy is formed.

The quality of castings depends on many factors. For example, when melting different metals, the alloy properties change and it is possible to get the alloy of the given quality with the correct selection of alloying and modifying additives. In production, experiments are carried out and express analysis of metal is performed, which determines the characteristics of the future product: its strength, porosity, and so on. While obtaining the casting, methods of influencing the casting by different cooling modes during its solidification were developed, such as blowing, adding a certain amount of water into the casting mold, vibration, etc.

Today one of the urgent tasks of foundry industry is manufacturing products with the composition known to manufacturers, and in case it is not known, which regimes should be applied in order to obtain the product with the given characteristics. Selecting an incorrect technological process, the founder can get the casting with defects, which is unsuitable for use. Also, assessment of the risk of appearance of casting defects depending on various violations of the process of manufacturing is the task not less important for founders.

Another topical task of foundry production is determination of the composition of additives, which are part of the metal charge used in alloys smelting.

After determining the components of the molten alloy, the technologist and the smelter can introduce the necessary additives to the melt, thereby obtaining the alloy of a certain chemical structure, which is used in further production.

By adding impurities to a solid charge or melt, experts are guided by tabular data, which at present are often outdated and need updating. Therefore, the purpose of this work is to create a computer system (technology), which will contain a comprehensive database of reference values of metals and alloys, their chemical and mechanical properties, information on various technologies of founding and cooling modes, as well as the sphere of application of finished products. For this, the founders need to know what chemical transformations occur when mixing different components of the alloy. Also, they must have information about the cooling modes of the given alloy, since different impurities react differently to certain cooling modes and, as a result, the founders get the casting of certain strength and quality.

\section{STATEMENT OF THE RESEARCH TASK}

Founding is not only a cost-effective method of manufacturing metal parts, but also the easiest to manufacture complex designs of castings. Founding is a technological process of casting production by filling a custom made mold by liquid metal through a channel system. After hardening, the casting is removed from the mold and sent for machining. In many cases, properties of pure metals do not meet the necessary requirements; therefore, alloys are used most often. Elements (metals and nonmetals), of which the alloy consists, are called alloy components. In the alloy, impurities are often present in addition to the main components. For example, bronze, which is the alloy of tin and copper, has a stronger hardness than each of its constituent metals separately. Therefore, alloys of metals are most often used in production.

By adding other metals or materials in a certain proportion to the mixture, it is possible to get many different products with a different structure and properties, even with those that are not characteristic of any pure metal.

Alloys, which are used for manufacturing various constructions, as a rule, must be strong. In construction and mechanical engineering, alloys of iron and aluminum are the 
most widely used. Such iron alloys, as steel, are of high strength and hardness, so they can be welded and forged.

Cast iron is used for manufacturing of most castings, including massive and durable parts of machines and mechanisms. For example, radiators of central heating, pressure and sewer pipes are casted from cast iron, as well as boilers, railings and supports of bridges. Cast iron products make up to $70 \%$ of the volume of foundry production.

Alloys of aluminum, which are used in constructions, are not only durable, but also lightweight. Duralumin and silumin are alloys of aluminum, which are irreplaceable in aircraft and carriage construction as well as shipbuilding.

In some assemblies of aircrafts magnesium alloys are used, which are light and durable. Lightweight and heat-resistant alloys based on titanium are used in rocket construction.

Alloys are an indispensable material for the manufacture of especially sensitive and high-precision devices, sensors of various types and energy converters.

Assessment of the risk of appearance of casting defects depending on various violations of the manufacturing process is an important stage in foundry industry.

The quality of castings is determined by the accuracy of their size, structure, mechanical and physical properties of the metal, the presence or absence of internal or external damages and defects in the form of cracks.

To control the structure of the castings metal, experiments on the cooling of various metals and their alloys under the influence of different modes on the cooling process were carried out at the Institute of Metals and Alloys of the National Academy of Sciences of Ukraine [1]-[3]. In [4] the authors constructed the models of dependence of the temperature change on the parameters, which influence the casting cooling process by the group method of data handling [5]. All that structured array of information in the form of an electronic reference database and software is needed to ensure its convenient use by technologists and designers of foundry production.

The selection of the cooling mode for the given casting and getting a qualitative product, which meets the requirements, is one of the elements of the information database, such as an electronic directory in the field of foundry production, which is developed by the authors.

\section{REVIEW OF EXISTING SOFTWARE IN THE FIELD OF FOUNDRY PRODUCTION}

At present, there are many different software products, which are used by technologists-founders at enterprises. Let us consider software tools, which are most widely used in the world, their main advantages and disadvantages (Table 1).

After reviewing the existing software available, in particular, for Ukrainian founders, we can draw the following conclusions:

1. All programs are very expensive; moreover, each of them requires continuous addition of supplementary components and the update of the old version of the program.

2. Programs are developed by specialists from different countries; therefore, they are written in the language of the developer and often have a complex interface, so their clarification and detailed instructions are needed.

\section{TABLE I}

PossibILITIES AND DisAdVANTAGES OF THE MOST COMMON SOFTWARE PRODUCTS USED IN FOUNDRY

\begin{tabular}{|c|c|c|}
\hline \begin{tabular}{|c|}
$\begin{array}{c}\text { Product name, } \\
\text { developer }\end{array}$ \\
\end{tabular} & $\begin{array}{c}\begin{array}{c}\text { Possibilities of process } \\
\text { modeling }\end{array} \\
\end{array}$ & Disadvantages \\
\hline \begin{tabular}{|l|} 
SolidCast, \\
Finite Solutions \\
Inc., USA
\end{tabular} & $\begin{array}{l}\text { 1. Metal pouring (fast and } \\
\text { normal) } \\
\text { 2. Solidification of metal: } \\
\text { placement of heat nodes and } \\
\text { shrinkage defects as well as the } \\
\text { prevention of the latter } \\
\text { 3. Automatic optimization of } \\
\text { sprue-feeding systems }\end{array}$ & $\begin{array}{l}\text { 1. Inconvenient interface } \\
\text { 2. Bad presentation of the } \\
\text { results of calculations for } \\
\text { visual analysis } \\
\text { 3. No Ukrainian database of } \\
\text { materials and alloys } \\
\text { 4. In the database of } \\
\text { properties there are constant } \\
\text { values for the whole } \\
\text { temperature range without } \\
\text { correction } \\
\text { 5. Long lasting computer } \\
\text { calculation } \\
\text { 6. Problems with the import } \\
\text { of STL }\end{array}$ \\
\hline \begin{tabular}{|l|} 
Magmasoft, \\
Magma GmbH, \\
Aachen, \\
Germany
\end{tabular} & $\begin{array}{l}\text { 1. Modeling of forms, filled } \\
\text { with metal } \\
\text { 2. Modeling of crystallization } \\
\text { 3. Calculation of tension and } \\
\text { deformation } \\
\text { 4. Modeling of structure, } \\
\text { distribution of perlite and } \\
\text { ferrite, etc. } \\
\text { 5. Recognition of different } \\
\text { types of casting: only casting } \\
\text { into sandy clay molds and } \\
\text { permanent mold casting in case } \\
\text { of the base version of the } \\
\text { program, and other types of } \\
\text { casting - with the help of } \\
\text { additional modules }\end{array}$ & $\begin{array}{l}\text { 1. High cost } \\
\text { 2. Very complicated } \\
\text { interface without } \\
\text { translation } \\
\text { 3. No Ukrainian database } \\
\text { of metals and alloys } \\
\text { 4. Big expenditure of time } \\
\text { for data input }\end{array}$ \\
\hline $\begin{array}{l}\text { CastCAE, } \\
\text { CT-CASTech } \\
\text { Inc. Oy, Espoo, } \\
\text { Finland }\end{array}$ & $\begin{array}{l}\text { 1. Casting under high pressure } \\
\text { 2. Casting under low pressure } \\
\text { 3. Casting by smelted models } \\
\text { 4. Permanent mold casting } \\
\text { 5. Sand molded casting }\end{array}$ & $\begin{array}{l}\text { 1. Elementary program, } \\
\text { for founding of simple } \\
\text { castings only } \\
2 . \text { No new versions of the } \\
\text { program in recent years }\end{array}$ \\
\hline $\begin{array}{l}\text { JSCast, } \\
\text { Osaka, Japan }\end{array}$ & $\begin{array}{l}\text { 1. Casting by smelted models } \\
\text { 2. Permanent mold casting } \\
\text { 3. Sand molded casting } \\
\text { 4. Casting under high pressure } \\
\text { 5. Metal pouring } \\
\text { 6. Solidification of metal: } \\
\text { placement of heat nodes and } \\
\text { shrinkage defects }\end{array}$ & $\begin{array}{l}\text { 1. Small range of program } \\
\text { features } \\
\text { 2. No Ukrainian database of } \\
\text { metals and alloys }\end{array}$ \\
\hline $\begin{array}{l}\text { AnyCasting, } \\
\text { AnyCasting } \\
\text { Co., LTD, } \\
\text { Korea }\end{array}$ & $\begin{array}{l}\text { 1. Metal pouring } \\
\text { 2. Solidification of metal: } \\
\text { placement of heat nodes and } \\
\text { shrinkage defects } \\
\text { 3. Calculation of tension } \\
\text { 4. Modeling of structure } \\
\text { Recognition of the following } \\
\text { types of casting: } \\
\text { 1. Casting by vacuum-film } \\
\text { mold } \\
\text { 2. Casting by smelted models } \\
\text { 3. Permanent mold casting } \\
\text { 4. Sand molded casting } \\
\text { 5. Casting under low pressure } \\
\text { 6. Casting under high pressure }\end{array}$ & $\begin{array}{l}\text { 1. No interface translation } \\
\text { 2. No Ukrainian database of } \\
\text { metals and alloys }\end{array}$ \\
\hline
\end{tabular}

3. All considered software products use finite difference methods and so they are not suitable to eliminate shrinkage porosity in castings of the responsible assignment because these methods work poorly in case of thin-walled castings, when the wall thickness is comparable with the grid step. 
4. Since some Ukrainian enterprises have slightly outdated equipment, many software tools developed on advanced computers cannot be used at such enterprises.

5. Another disadvantage of the above described programs is the absence of the Ukrainian database of metals and alloys that complicates the work of founders.

\section{CREATION OF THE DATABASE FOR THE INFORMATION DECISION SUPPORT SYSTEM OF FOUNDRY PRODUCTION: ELECTRONIC DIRECTORY "FOUNDER ADVISER"}

In papers [6], [7] the tasks are presented, which must be performed by the information technology of inductive modeling of foundry production processes, as well as its block diagram. Such system consists of three blocks, which model the following tasks:

1. An electronic directory of designing the technology of castings production and information on products, which can be obtained from metal or alloy.

2. An electronic directory, according to the customer's technical specifications, on the selection of charge materials and alloys smelting, including sampling, express analysis and adjustment of the composition in order to obtain high-quality castings.

3. An electronic directory of processes of founding and cooling in order to select the best mode.

Let us consider each of the tasks in detail.

Task 1. Designing the technology of castings production and information on products, which can be obtained from metal or alloy according to the customer's technical specifications.

The specialists, who deal with casting, know familiar metals and alloys to a sufficient degree, with their costs and suppliers indicated. They can choose the available metals from the database and find out, which typical products can be obtained from them. So, at the first stage, the specialist can choose the field, in which it is planned to use this product. Fig. 1 shows the options of such choice.

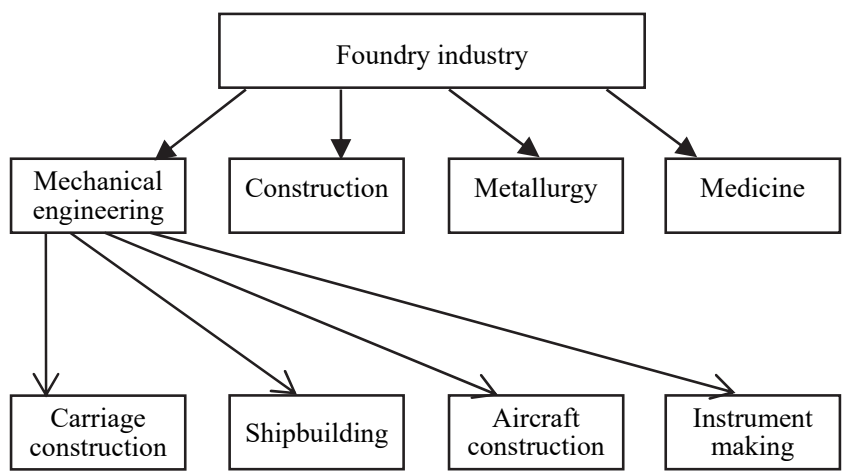

Fig. 1. The proposal for selecting the necessary field of casting application.

When the designer determines the field, in which s/he will work, the program will invite the user to choose a "sub-field". In Fig. 2 the example of possible sub-fields is given.

For example, if the user selects the field "Engine building", $\mathrm{s} /$ he will receive the spheres of application in this area (Fig. 3).
When the specialist chooses the sub-field, s/he will be asked to select from the existing database exactly the material, which will be specified by the customer.

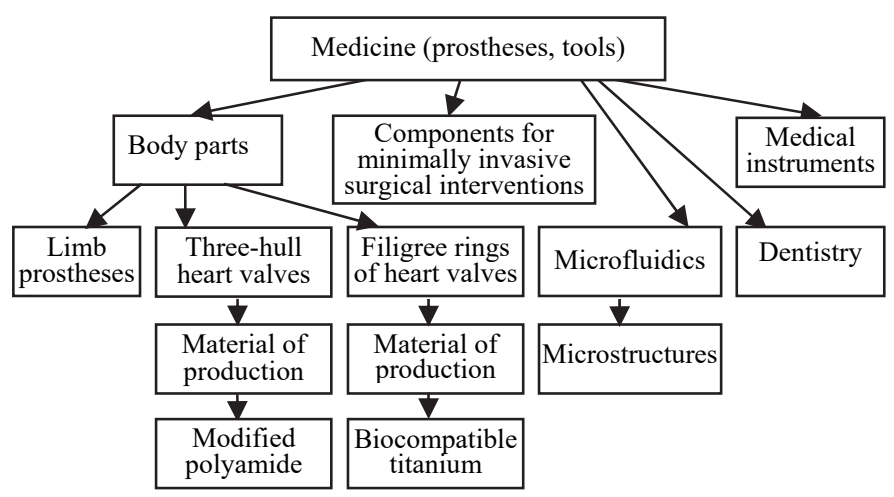

Fig. 2. The example of the sub-field of application for the product from the casting.

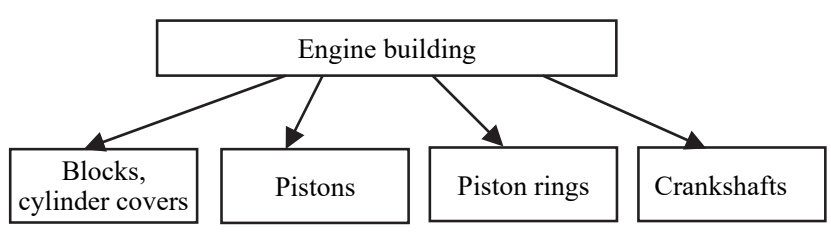

Fig. 3. The example of possibilities of application in mechanical engineering.

Next, the program will consistently suggest choosing the next settings: equipment for getting the casting, melting methods and cooling modes for chilling the casting, in particular, those which meet National Standards of Ukraine as well as European GMP standards.

After setting up all the necessary parameters and criteria for obtaining the finished casting, the user sets the "START" of the program.

After completing the work, the specialist puts the task of evaluating the product for probability and prevention of defects and spoilage.

Then, after conducting the necessary express tests, the specialist comes to agreement on the product with the customer. If defective parts are found, the program is corrected.

Task 2. An electronic directory on the selection of charge materials for alloy smelting.

The specialist, who uses this system, has scrap metal (other components of the charge) with an unknown composition, which s/he wants to use for further founding in order to obtain a definite product with given properties.

First, the chemical analysis of this scrap or the charge components is carried out presenting all components and their amounts in the alloy on the screen.

Then, the obtained results are compared with the standards from the database in order to determine if the alloy is known and whether it is possible to use it to obtain the necessary casting.

The conclusion of the program will be whether the given alloy is suitable for getting the finished casting or the software 
will offer instructions on how to adjust this alloy by introducing new components.

If the alloy is suitable, it is necessary to set the pouring modes and the desired product will be obtained. If not, then it is necessary to calculate which components and in what amount are needed in order to get the alloy with the given properties.

The program recommends the technique of scrap sorting, optimizes the charge composition by cost, offers the sequence of charging, melting regimes and the temperature of the melt release.

Task 3. An electronic directory for processes of founding and cooling of the casting.

The specialist concentrates one's attention on getting the castings, which meet the given criteria, and therefore sets the necessary parameters of the processes of founding and forced cooling in the software. The specialist can keep under control the whole process of the casting production, from its melting to hardening, and in case of the program failure can restart the whole process from the beginning.

This section includes the use of the database for the thermal analysis of alloys and typical castings, has a reserve space for creating a directory of the casting thermal treatment, including the thermal treatment of the cast state.

\section{CONCLUSION}

In this paper the technology of developing an information database system is characterized, namely the electronic directory of foundry production. It will allow the specialist in the field of founding to obtain automatically technological schemes subject to the choice of the field, where the given metals and alloys can be used, or, in case of the unknown alloy and charge materials, to obtain products of the given quality.

\section{REFERENCES}

[1] V. S. Doroshenko, O. I. Shinskiy, and V. P. Kravchenko, "Intensification of Heat Exchange of the Casting with the Dispersed Filler of the Mold when Using Refrigerant and Forced Convection," (in Russian), Casting Processes, vol. 5, pp. 74-82, Kyiv, 2009.

[2] V. P. Kravchenko and O. V. Kravchenko, "Remote Eco-Monitoring of Technological Processes in Industry," (in Russian), Zaporizhzhia, IX International scientific conference "Casting. Metallurgy. 2014", pp. 54 $56,2014$.

[3] V. P. Kravchenko and O. V. Kravchenko, "Construction of Mathematical Models for the Analysis of the Results of Operational Monitoring of Objects and Processes in Foundry Production," (in Russian), Varna, International Scientific Journal Acta Universitatis Pontica Euxinus, Special number of IX International Conference "Strategy of Quality in Industry and Education", vol. 3, pp. 489-491, 2013.

[4] Ye. A. Savchenko and O. V. Kravchenko, "Application of the Inductive Approach for Modeling the Casting Cooling Process According to the Experimental Data," (in Ukrainian), Inductive modeling of complex systems, Kyiv, International research and training center for information technologies and systems, vol. 6, pp. 126-136, 2014.

[5] A. G. Ivakhnenko, Inductive Method of Self-Organizing Models of Complex Systems, (in Russian). Kyiv: Naukova Dumka, 296 p., 1982.

[6] O. V. Kravchenko and Ye. A. Savchenko, "Information Technology of Inductive Modeling for Monitoring of Foundry Production Processes," (in Ukrainian), Inductive modeling of complex systems, Kyiv, International research and training center for information technologies and systems, vol. 7, pp. 140-146, 2015.
[7] O. V. Kravchenko and Ye. A. Savchenko, "Development of Information Technology of Inductive Modeling for Monitoring of Foundry Production Processes," (in Ukrainian), Proceedings of the III International Conference on Automatic Control and Information Technologies ICACIT-2015, Kyiv, pp. 116-117, 2015.

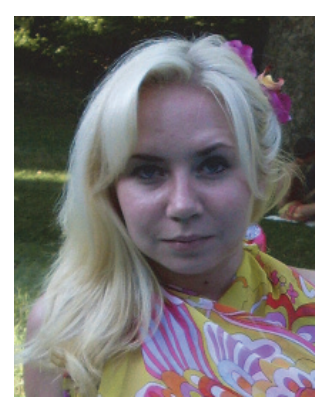

Tokova Olena. From 2012, post-graduate student of International Research and Training Center for Information Technologies and Systems of NASU-MESU, Ukraine. From 2011, Mathematician-Programmer, the speciality "Applied Mathematics" (The Saint Grand Princess Olha Institute for International Economics, Finance and Information Technology of the Interregional Academy of Personnel Management, Ukraine). Current position: Software Engineer at Glushkov Institute of Cybernetics of NASU, Ukraine.

Major areas of scientific activity are the group method of data handling (GMDH) and other methods of inductive modelling under assumptions; robotics problems on using a mobile robot manipulator for repair and rescue works under extreme conditions of catastrophic situations in underground mining constructions; ecological problems on development of geoinformation systems for the prediction of natural meteorological disasters; the interval method of telemetry information reliability control for monitoring the casting cooling in a sand mold; mathematical methods for assessing the quality of cast iron by temporal experimental data; monitoring and geoprocessing of the earth surface probing processes. Author of more than 20 papers, published in scientific journals and presented at international and Ukrainian scientific conferences.

E-mail: len327@ukr.net

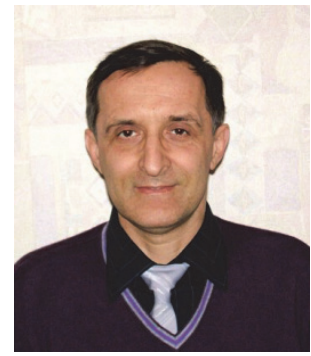

Doroshenko Volodymyr. From 1990, Ph.D. in Technical Sciences. The PhD Thesis "Obtaining of Castings of Hydrodistributors from Cast Iron with Globular Graphite in Vacuum-Processed Molds" was defended at Kyiv Polytechnical Institute, Ukraine. From 1982, Engineer, the speciality "Foundry of Ferrous and Nonferrous Metals" (Kyiv Polytechnical Institute, Kyiv, Ukraine). Current position: Senior Research Fellow at Physico-Technological Institute of Metals and Alloys, Ukraine.

Major areas of scientific activity are heat and mass transfer, gas and hydrodynamics of the interaction of a melt and a crystallizing metal with a sand casting mold, physics and chemistry of processes of sand casting molds production, particularly with the use of vacuumization; new methods of forming for foundry, which ensure an environmental safety of production and improve the quality of metal castings; methods of casting into vacuumprocessed molds; use of cryo-technologies in foundry, in particular, technological bases of accurate blanks obtaining by single-use ice models. Author of more than 340 scientific and technical papers, including about 80 patents for inventions of Ukraine and Russia.

E-mail: doro55v@gmail.com

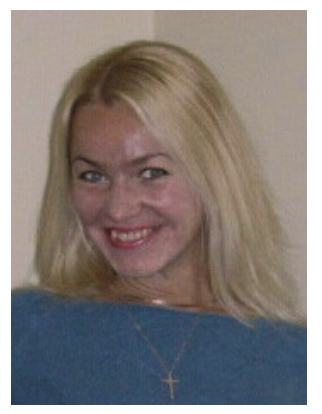

Mul Olena. From 2001, Ph.D. in Physics and Mathematics. The PhD Thesis "Analysis of Self-Oscillation Processes in the Complex Continuous and Discrete Systems" was defended in Space Research Institute of NASUNSAU, Kyiv, Ukraine. From 1994, EngineerMathematician, the speciality "Applied Mathematics" (State University "Lvivs'ka Politekhnica", Ukraine). Current position: Associate Professor of Computer-Integrated Department of Ternopil National Ivan Puluj Technical University, Ukraine.

Major areas of scientific activity are control theory on time scales with a special emphasis on hybrid systems; controllability and optimality of nonlinear control systems; analysis and control of dynamical systems; numerical analysis; perturbation theory; theory of vibrations; mathematical physics and computational mathematics for nonlinear boundary value problems in PDE's and ODE's. Member of IAMP. 
Grants of INTAS, IUPAP, NATO, ESF, UNESCO, CIME, C.I.R.M., the Banach Center (Warsaw, Poland), Max Planck Institute of Physics of Complex Systems (Dresden, Germany). 3-year FCT Post-doctoral fellowship "Analysis of Vibrations in Nonlinear Dynamical Systems" at Department of Mathematics, University of Aveiro, Portugal (2004-2007). 6 months scientific fellowship "Numerical and Asymptotical Methods for Highly Oscillatory Differential Equations" at the Department of Applied Mathematics and Theoretical Physics, Centre for Mathematical Sciences, University of Cambridge, UK (2012).

E-mail: ms.olena@gmail.com

Liešanas ražošanas induktīva tehnoloǵija elektroniskās datubāzes izveidošanai Olena Tokova ${ }^{1}$, Volodymyr Doroshenko ${ }^{2}$, Olena $\mathrm{Mul}^{3}$

${ }^{1}$ International Research and Training Center for Information Technologies and Systems, Ukraine

${ }^{2}$ Physical-and-Technological Institute of Metals and Alloys, Ukraine

${ }^{3}$ Ternopil National Ivan Puluj Technical University, Ukraine

Ir ierosināta metožu izstrāde informācijas elektroniskajam katalogam ar tajā ietvertu metālu un sakausējumu datu bāzi metāllējumu produkcijas joma liešanas produkcijas jomā Pēdējais ir paredzēts liešanas ražošanas tehnoloğijas attīstī̌sanai, ieskaitot pieejamo izejvielu analīzi, liešanas komponentu mērḳa izvēli, kā arī dzesēšanas režīmu izvēli, lai iegūtu augstas kvalitātes lējumus. Atslēgas vārdi: Informācijas tehnoloğija, lēmumu pieṇemšana, lējumu dzesēšana, metālu un sakausējumu datu bāze. 